\title{
Economic Surplus, Social Reproduction, Nurturance and Love
}

\section{Phillip Anthony O’Hara}

Global Political economy Research Unit, Economics Department, Curtin University, Perth, Australia. philohara@yahoo.com

\begin{abstract}
This paper examines the contributions of James Ronald Stanfield to social and political economy. ${ }^{1}$ We start the analysis with Stanfield's contribution to institution building through his education of PhD students, building a graduate program in political economy, and through the associations of social and political economy. Then we go on to scrutinise his creative developments and applications of the notions of economic surplus and social reproduction. This is followed by his extensive work on Karl Polanyi and the disembedded economy. Finally we explore his path-breaking analysis of the great capitalist restoration, the nurturance gap and love. Stanfield was one of the greatest institutionalists and social economists of the last hundred years, and these four areas of energetic creativity are his prime achievements in the area.
\end{abstract}

Keywords Economic surplus • Reproduction • Disembedded Economy • Nurturance • Love

\section{Introduction}

James Ronald Stanfield was born into a poor working class family on 22 November 1945. He was brought up in Handley, Texas, a semi-rural area at the time, went to Eastern Hills High School (in Fort Worth), and was a practicing Methodist until the age of 14. His parents were of Irish-Scottish and German ancestry, and worked in a short order café, competing with the emerging take away fast food joints. In his late teens he took to economics as a way of getting out of the culture of poverty, expecting to become an "efficiency expert" or what is now called a Management Consultant. With this in mind he took a B.A. (1968) with a major in Economics and an M.A. in Economics (1969) at the University of Texas at Arlington.

By this time he was drawn into the protests against the Vietnam War and lost his interest in being an efficiency expert, being more concerned with the excesses of the corporate state, the wasteful use of public spending, and the need for more caring foreign and domestic policies. Ron, as his friends and colleagues call him, was then drawn to the new groupings of institutionalists and neo-Marxists who started to organise conferences and journals in the US in the mid-late 1960s. Following this radicalisation he did a PhD thesis on the economic surplus at the University of Norman (1972). His first real love, however, was neither Karl Marx nor Thorstein Veblen, but his friend and roommate of several years, Jacqueline Sue Bloom (b. 1947) who made an impressionable influence on him during and for decades after their '67 spring of love.

These were, after all, passionate times, with the anti-war and civil rights movements gaining momentum, while feminism was bringing women in the official workforce. Martin Luther King had been assassinated in 1968, students were killed at Kent and Jackson State in 1970, and campus activity

\footnotetext{
${ }^{1}$ I wish to thank the referees, participants of the festschrift celebrations in Boston, and Ron Stanfield for useful comments on earlier versions of this paper. An early and very brief version of this paper was published as O’Hara (2006a). Many thanks go to Ron Stanfield for decades of stimulating analysis and friendship.
} 
was rife vis-à-vis the US invasion of Cambodia and Vietnam. The Cold War was in full swing as the USSR-US played the Mutually Assured Destruction game; Castro continued a socialist revolution in Cuba; while Neil Armstrong became the first man to walk on the Moon. Cultural transformation saw radical revolt in Paris, a cultural revolution in China, while socialism with a human face was defeated by Russian tanks in Prague.

The baby boom generation was leading the field for social reform world-wide, not only in politics, but also music, art, education and work. A cultural renaissance seemed to be in motion as the old gave way to the new, and social innovations were impacting on every facet of life. Alternative lifestyles were springing up; love, peace and meditation called many to alternative states of consciousness; holistic health movements were sprouting; while rock music fused with rhythm and blues, folk, soul and classical to create new forms of harmony and rebellion.

The times were certainly a-changing as the Un-American Activities Commission in the 1950s and early 1960s fell in the face of the counter-cultural and radical social change of the 1960s and early-mid 1970s. Many young people came under the influence, directly or indirectly, of radical politics and social change movements. Students for a Democratic Society, which Ron joined in 1968, played a prominent role in these changes. People began to be concerned about the environment, alienation in the workplace, over-consumption in the marketplace, conventional standards of dress and behaviour, corporate control of society, and the destructive influence of nationalism and economic growth on society and the environment.

A new world was on the horizon while a freshly minted PhD student in political economy named Ron Stanfield tried to make sense of these personal and cultural transformations. His world of ideas was stimulated by greats such as John Kenneth Galbraith, Paul Baran, Paul Sweezy, Herbert Marcuse, and Thomas Kuhn. Galbraith was writing about the sociocultural ramifications of the new industrial state, Baran and Sweezy the contradictions of monopoly capital, Marcuse the oppressive strictures of modern technology, while Kuhn opened people's eyes to various ways of seeing the world. These fresh ideas gave young Ron an apprenticeship for understanding institutional adjustment through cultural change.

Indeed, Stanfield's major contributions to institutional and social economy lay precisely in this concept of institutional adjustment through cultural change. He sought to analyse the impact of cultural transformation on the institutions of advanced capitalism, and the potential for progressive social change that arose out of this evolutionary metamorphosis. In reviewing his body of work we start by documenting Ron Stanfield's activities in professional institutions. We then go on to analyse his contributions to the economic surplus approach and the process of social reproduction. Following this we examine his analysis of the disembedded economy and principles of socioeconomic integration. Lastly we explore the Great Capitalist Restoration, the nurturance gap and his critique of neoliberalism. Throughout this paper we concentrate on the processes of institutional change and the principles of political economy that enable one to comprehend cultural metamorphosis and transformation. We conclude the paper by sketching a research program for the future that builds on Stanfield's contributions to scholarly inquiry.

\section{Stanfield's Contributions to Institution Building}

Ron Stanfield has contributed much to an understanding of institutional change. It is not surprising, therefore, to find that he played a leading role in institutions themselves (see Table 1 for a summary). He had in the late 1960s joined the Union for Radical Political Economics (URPE) and Democratic Socialists of America (DSA), to illustrate his commitment to radical change. Then he became an active member of the Association for Evolutionary Economics (AFFE), and for more than three decades has been active in advancing the cause of institutional economics. For instance, he has published 21 articles in AFEE's Journal of Economic Issues (JEI) on subjects ranging from Kuhnian revolutions to linkages between institutionalism and Marxism, the current crises of capitalism, the institutional economics of Polanyi, Galbraith and Ayres, monopoly capital and the role of the state, and the nature of nurturance 
and love. He also served on the Editorial Board of the JEI (1978-1981) as well as being a member of the Board of Directors of AFEE (1981). In 1998 he became the President of AFEE and delivered a paper on "The Scope, Method and Significance of Original Institutional Economics” (Stanfield 1999) in that capacity. In January 2006 in Boston he received the greatest accolade possible in political economy, the Veblen-Commons Award, for his outstanding contributions to institutional economics.

Table 1 near here

In the late 1970s, the Association for Institutionalist Thought (AFIT) was formed with a view to going back to the roots of institutional economics through the work of Thorsten Veblen, Wesley Mitchell, John Commons and Clarence Ayres. At the time, AFEE was taking a rather eclectic role in analysing different varieties of institutional economics and the linkages between institutionalists and Marxists, neoclassicists and public choice theorists. The idea was that AFIT should redirect the activities of institutionalists to the core of its discipline. AFIT even developed an alternative journal, the Review of Institutional Thought, edited by Dale Bush through 1980-1983. After playing a core role at many of their yearly conferences, Stanfield became President of AFIT in 1995.

Ron also played a critical part in the Association for Social Economics (ASE), an organisation that in an earlier life had been a vehicle of Catholic economists and since the 1960s had become more heterodox and inclusive for economists concerned with the role of values and ethics. Early on he received the Helen Potter Award for the best article published in ASE's Review of Social Economy (RoSE) for 1975, “On the Crisis of Liberalism”, where he outlined the problems of liberal democracy in the light of the contemporary crises of capitalism. During 1980-82 he was an elected member of the Executive Council, being engaged in the administration of ASE. He became a Guest Editor for a 1992 issue of RoSE on "Economy and Society at the Close of the American Century", a member of the Editorial Board for the past sixteen years, and President of ASE during 1993. In 2002 he was presented with the Thomas Divine Award for Lifetime Contributions to social economics.

But his most critical contribution to institution-building was at Colorado State University, where he started as Assistant Professor of Economics in 1974, became Associate Professor in 1976, and then Full Professor in 1981. At Fort Collins he was Coordinator of Graduate Studies during 1982-1990 and 2000-2003; taught regular units in institutional economics, Marxian economics, comparative political economy and the history of economic thought; and received both the Pennock Distinguished Service Award for 1988-89 and the John H. Stern Distinguished Professor Award in 1999. He was energetic in building a strong undergraduate and $\mathrm{PhD}$ program in political economy, with the able assistance of Ronnie Phillips. $^{2}$

For over thirty years Stanfield shared his wisdom of cultural advance through institutional adjustment with several generations of students at Colorado State. For instance, he was the Principal Supervisor for $17 \mathrm{PhD}$ students, including dissertations on such diverse topics as Marxian, heterodox, Catholic, Austrian, and Budapest schools; the political economy of Robert Heilbroner, John R. Commons, and Rexford G. Tugwell; plus the role of culture, welfare, housing, labor, information, transitional economies, and media. He was a supervisor for well-known institutionalists such as Raymond Benton, Douglas Brown, Michael Carroll, Douglas Kinnear, Aric Krause, and Brent McClintock, plus numerous rising stars such as Pamela Jackson, Kurt Keiser, Thomas Kemp, Robert LaJeunesse, Laura Taylor, Mary Wrenn and Tim Wunder.

A number of his students have contributed a great deal to institutional and social economics. For instance, Doug Brown has published many journal and book articles, as well as books on Towards a Radical Democracy (1988), The Economic Status of Women Under Capitalism (1994), Thorstein

2. Ronnie Phillips has published widely in institutional economics and money and finance (see Phillips 1995a, 1995b). Ronnie Phillips has been an especially close colleague of Ron Stanfield's, including their linkages to the Association for Evolutionary Economics (AFEE), the Association for Institutionalist Thought (AFIT) and to some degree through the Union for Radical Political Economics (URPE). 
Veblen in the Twenty-First Century (1998) and Insatiable is Not Sustainable (2002). Raymond Benton has analysed many areas of environmental studies, including ethics, racism and management. Michael Carroll has researched the work of Robert Heilbroner, social capital and regional development. Douglas Kinnear has examined recent trends in information technology, including theoretical implications for policy, the nature of open source software and the MP3 revolution. Brent McClintock has scrutinised the welfare state, international economics and more recently the legal foundations of capitalism.

But what is it, fundamentally, that Stanfield and many of his students have been concerned with? The main research focus has been centred on "the fundamental term, institution", which he defined as "clusters of moral beliefs that configure power", where "the power in question concerns those transactions that exercise governance in the process of material reproduction", since "the economy ... is an instituted process for material provisioning" (Stanfield 1999: 233). Institutional dynamics have been the central message of their work; in other words, "the process of institutional adjustment" resulting from innovations and inventions in economic life. Concentrations of power in economic life flow to those who have access to the vast resources emanating from successful changes to the means of production, distribution and exchange. This power is not always allocated on the basis of 'effort and creative contribution', as various classes have unequal resources based on upbringing, group networking, coercion, and intimidation.

The central questions of political economy are therefore: What classes of people gain access to the "economic surplus" after various costs of (re)production, are deducted; what institutions contribute (or otherwise) to the production, distribution and exchange of this surplus; and what are the ramifications for the reproduction of society of successive technical and organisational changes to economic life. J.K. Galbraith is especially important for Stanfield's research given his emphasis on the interplay of institutions, power and the public/private distinction (Stanfield 1996). It is to these questions that we must commence the story about Stanfield's contributions to institutional and social economy.

\section{The Economic Surplus and Social Reproduction}

Ron Stanfield's major contribution to social and political economy lies in comprehending socioeconomic and cultural change. Three such areas are especially conspicuous in his work. The first relates to the production, distribution and reproduction of the economic surplus. The second is the contradictions promoting periodic and structural social instability and crisis among capitalist economies. The third links to the need for human societies to be protected from the ravages of change, dislocation and crises typical of free market economies. We deal with each of these in turn.

Stanfield was one of the first to analyse the dynamics underlying the production and distribution of the 'economic surplus' in the wake of Paul Baran and Paul Sweezy's (1966) scrutiny of Monopoly Capital. This he did in his PhD thesis at the University of Oklamoma, Norman, under the supervision of Tom Curtis and Nelson Peach. Almost immediately a version of the thesis was printed by a commercial publisher, Lexington Books in Massachusetts, as The Economic Surplus and Neo-Marxism (Stanfield 1973). At a time when radical political economy was in its heyday, books and articles on the operational dynamics of contemporary capitalism were much in demand. Baran and Sweezy were the parents of this intellectual movement, and Stanfield was one of the most conspicuous offspring to emerge.

Being dedicated to "Paul Sweezy and the memory of Paul Baran", the book sought to study the significance of the economic surplus, the nature of essential personal and social consumption and an estimation of essential consumption, potential output and the economic surplus. Three of Baran and Sweezy's main hypotheses are critically examined, and two of them are found to be problematic. The main hypothesis of a strong and systematic tendency for economic surplus to rise, "both absolutely and as a share of total output" was found to be consistent with the evidence for the US during 1932-1970. Both potential and actual surplus tended to rise, with some slight falls during a few years which did not 
negate the main tendency (Stanfield 1972: 81). Thus, advances in knowledge, technique, skill and effort enabled the economic surplus to advance through time during most of the twentieth century.

The two hypotheses found to be questionable were especially important to a critical analysis of modern capitalism. The first of these is the idea that the investment portion of the surplus tends to rise, and the second is that the normal state of monopoly capitalism is one of stagnation. Stanfield found that the investment portion did not tend to rise because of the importance of resources for reproducing the social classes and the institutions of society. He similarly found that there is no inherent tendency in capitalism for stagnation because the institutions are often able to be reconstructed to deal with anomalous trends (Stanfield 1974). These two findings are critical to the further development of Stanfield's thought and political economy.

These two revisions of Baran and Sweezy's work on monopoly capitalism are ones that most political economists have, even now, failed to recognise, since they reflect fundamental innovations that are often difficult to propagate. As Dale Bush (1999) recognised, institutional innovations are often inhibited by the entrenched vested interests and social classes. The first innovation contributed by Stanfield was the concept of socioeconomic reproduction. Of all the political economists of the last hundred years, no one has made more contributions to this than Stanfield. It is understandable, then, that 'reproduction' became the central theme of his second book, Economic Thought and Social Change, published by Southern Illinois University Press in 1979 (Stanfield 1979) and many articles of his.

He recognised socioeconomic reproduction requires quite considerable resources for long-term continuation and advancement. One might even put forward that these resources necessarily expand through time as society becomes more complex and geographically dispersed. Political economists have long recognised the productive structure of industry requires resources for simple and extended reproduction - replacement of machinery, factories and inventories; plus expansion of these resources for growth (Marx 1885). Gradually they came to realise that the knowledge and skill structure of labor also needed to be reproduced and expanded through human capital. Later they even extended this to the reproduction of the environment through the maintenance of ecological capital, and more recently that trust and networks of relations are essential to business and society.

Stanfield's view of reproduction was holistic inasmuch as he recognised the degree to which all these durable forms of capital need to be both maintained and expanded. But much more than most he saw that strong sustainability is of prime importance. He rejected the orthodox view of the need to expand corporate and market relations at the expense of social relations, since the destruction of culture and sociality may fail to be replaced with a viable social dynamic. More especially, once the institutions of love and nurturance are downplayed in favour of money and personal advancement it may be difficult to reconstruct such intimate relationships, given the path-dependent, irreversible nature of socioeconomic processes. Hence, he saw the need for a grand social science with a vision of the totality of life's processes and resources. The orthodoxy of neoclassical, Marxian and institutional economics failed to provide such a vision. ${ }^{3}$

However, Stanfield was not convinced that such a grand vision would succeed, nor that social change would be adequate to the task. Because of that, he set about institution building and developing also the notion of a fund for social change. The fund for social change is the economic surplus, which is the discretionary income of society that can potentially be democratically distributed and absorbed

3. Stanfield makes the point in a number of places that orthodox economics may fail to advance due to the classes and interests they seek to promote, and therefore a paradigm may stagnate. One of the reasons for having alternative perspectives in economics is to ensure that paradigmal change is possible, even if the orthodoxies take innovations from these heterodox visions with insufficient acknowledgement. On the other hand, orthodox economics may fail to sufficiently innovate. As he, for instance, said: "There always exists the possibility that a paradigm will resist revolution and simply decay. That is, a paradigm may be sufficiently institutionalized to suppress alternative paradigms, even to the point of glossing over fundamental crises. The competitive market model has withstood myriad attempts to inject into it elements of power, polity, or class struggle. ... As such, social science is forever a potential weapon of propaganda, and this facet is in continuous tension with that of man's desire to know himself" (Stanfield 1974: 105-106). 
according to the prevailing social visions. The economic surplus (ES) is the difference between potential output (PQ) and essential reproduction requirements (ER) (Stanfield 1974):

$$
E S=P Q-E R
$$

Potential output is a function of the stock of knowledge and capabilities, whereas essential reproduction involves resources for maintaining the stock of knowledge, skills, communication, sociality, transport, nurturance, love and friendship. A minimum of resources are required for essential reproduction, concerning not only essential consumption for all people but also expenses for education, health, infrastructure, and essential services.

What is left over (ES) is the fund for social change. There are many ways in which this surplus can be absorbed or utilised. Society can decide whether to put part of the surplus into investment in physical capital. Communities can reduce the stock of greenhouse gasses for future sustainability. Groups of people can decide to expand the supply of beautiful and artistic endeavours of the arts and humanities. Democratic improvements can be made to the work environment to reduce alienation and subordination. Resources can be put to enhancing love, sociality and trust in the major institutions. Society can also decide to put more resources into resolving conflict and improving the workings of underdeveloped nations. Many of these activities can themselves enhance the level of the economic surplus through dynamic feedback processes that enhance (re)productivity and demand.

Stanfield emphasises the qualitative nature of the reproductive environment. What is the point, for instance, of expanding consumption and economic growth at the expense of losing friendships, destroying the environment, and having no time left for love and nurturance that heightens our humanity? Stanfield uses Baran and Sweezy's economic surplus analysis as an argument to centre on the quality of the social environment, and the psycho-cultural consequences of enhancing corporate power and class divisions. In this, he is deepening Baran and Sweezy's analysis of "The Irrational System" in chapter 11 of Monopoly Capital, where they explore the "contradiction between the compulsions of the system and the elementary needs of human nature becoming ever more insupportable", and hence to "the spread of increasingly severe psychic disorders leading to impairment and eventual breakdown of the system's ability to function even on its own terms" (Baran and Sweezy, 1966:350).

Stanfield's main contribution, though, was in recognising that it is not simply a question of "providing resources" for essential consumption and social change. More critical is the long term cultural process of people using their time reproductively to actively promote a nurturing, friendly, loving, and participatory social environment. The first best option is to take a long view where the culture is integrated instrumentally in progressive ways through the endogenous dynamics of social habits and institutions. The second best position is where the state (or other elements) reacts to insufficient integration through various social projects for protection. The third best option is where the market destroys family, community and environmental sustainability which itself inhibits long-term economic development. As Stanfield says:

From the low economic surplus of early capitalism we have moved to a high surplus economy. Indeed, it can be argued that a great deal of output today is not only surplus but superfluous. The economic superfluous has not been measured or even adequately conceptually defined, but much of the resources devoted to advertising, planned functional obsolescence, and military programs must surely fit the category. Implicit in this judgment is, of course, the definition of the economic superfluous as that output or resource use which is not progressive in the sense [of] ... contributing to human progress. [Stanfield 1975: 16-17] ${ }^{4}$

4. The question arises as to whether thirty years later we still have an insufficiently developed system of statistical analysis that fails to include these questions of superfluous goods and services. In particular, do they include questions about unproductive military spending, planned obsolescence, the waste of excessive packaging and advertising, and the obsession 
This concern of Stanfield for the psycho-cultural consequences of an insufficiently progressive reproduction of the social economy led him to examine crisis tendencies of capitalism. He saw a close link between the inability of capital to suitably reproduce the social-cultural integrity of the system and the emergence of economic crises and financial instability. This led him to the concept of system contradiction where there are inconsistencies between the interests of individual persons and companies and the viability of the system as a whole. System contradictions imply that resources and energy need to be directed to the coherence of institutions in the larger cultural environment. A lack of coherence leads to conflict, instability and problematic socioeconomic performance. Stanfield's work thus involved analysing the national and international structural crises that emerged in the 1970s-2000s.

He therefore came to support the concept of long waves in the political economy of institutions, broadly in line with the work of radical political economists (O’Connor 1984; Bowles, Gordon \& Weisskopf 1994). Stanfield and radical political economists believe that integrative institutions are necessary for long-term socioeconomic performance. Such institutions can, however, only work for a time as their contradictions gradually begin to dominate. Contradictions are dysfunctional processes that both enable the institutions to work effectively (for a time), and also predicate their demise. Institutions are constantly changing, to varying degrees, and eventually the linkages between institutions and their individual functioning heighten the dysfunctional aspects. This manifested itself, for instance, in increasing conflict, instability and discontinuity for the US and global capitalism during the 1970s-2000s. ${ }^{5}$

The central contradiction of capitalism emanates from the combined insights of Marx, Schumpeter and Polanyi. Capitalism is forever changing as firms innovate to beat their competitors, workers upgrade their skills and change location to be employed, consumers seek ever-more fanciful goods and services to be ahead of their neighbours, and communication media generate the most extreme and impressive visual effects to bring in new customers. Things are required to be bigger, better, and brighter while change is ongoing and successively more radical. The very essence of capitalism is thus change and motion. Yet this is in contrast to the needs of human beings for some minimal degree of stability, a caring environment, a trusting community. As Stanfield said re the problem of power and reproduction:

Consider now the implications of the process of creative destruction for culture and society. With respect to culture, the incessant change makes it difficult for the individual to sustain an ordered model of the world and [their] place in it. ... Social reproduction means society is reproduced as a going concern. This requires reproduction of its vital occupations and economic functions. Since social change is ever present, this also requires adjustment in this process of reproduction. ... Livelihood means the economic process of provisioning. What must be asked of this livelihood is that it reproduces lives without disrupting them and retarding the development of individuals. The acceptance of social disruption and stunted individual

with growth rather than quality of life, long-term progress, and strong sustainability. No current well-known statistical technique seems to adequately examine it from an economic surplus point of view. But perhaps the closest we get to it is the Index of Sustainable Economic Welfare or the equivalent Genuine Progress Index. For detail on this see, for instanced, the work and survey of Phillip Lawn (2002).

5. Stanfield wrote much more on the notion of contradiction, some of which is detailed in the further sections of this paper. One way to look at the contradictions, as he saw the matter, was "to think of capitalism as a system of institutionalised externalities” (Stanfield 1992:140). These external costs are not internalised into prices and are often born by workers, the environment, society, and so on. One central one is alienation and moral degradation of workers through denying them the power of cooperative management in the workplace. Another is the continual ravages of the environment through pollution, habitat destruction, over-exploiting resources, and eventually declining biodiversity and global warming. All this is part of the process of producing an economic surplus that can be used to increase profit, chief executive salaries and bonuses, and the whole cast of unproductive retainers and hangers-on essential for the ceremonial encapsulation of technology and production systems. 
development in the name of efficiency is patently absurd from this point of view. In the name of getting as much of the means as possible, the sacrifice is made of the very ends to which these means are to be directed. [Stanfield 1982:79, 80, 81] ${ }^{6}$

This led to a broader recognition of a close connection between institutional, neo-Marxian and radical political economy. Institutional economics has a long tradition from Thorsten Veblen to John Commons through to Wesley Mitchell, Clarence Ayres, John Kenneth Galbraith and others. NeoMarxism has its roots in Marx and more modern authors such as Baran and Sweezy, Ernest Mandel, Anwar Shaikh and Harry Braverman. Radical political economy arose in the late 1960s under the influence of Karl Marx through analysing the institutional limits of late capitalism, especially in segmented labor markets, monopoly capital enterprises and conflictual family environments. Some of the leading light of this group include Sam Bowles, Herbert Gintis, the late David Gordon, Thomas Weisskopf, Richard Edwards and Michael Reich. From these roots emerged the trend of "radical institutionalism” through the work of Rick Tilman, Ron Stanfield, Bill Dugger, Ann Jennings, and a host of other scholars. ${ }^{7}$ Radical institutionalism thus emerged as a critical movement in modern political economy recognising especially the symbiotic linkages between Marxism and institutionalism. As Stanfield (1977: 68) says, they "can learn from [each] other and perhaps be strengthened by synthesis." 8

Radical institutionalism thus analyses the role of institutions in solving problems of conflict, instability and cultural malaise. It includes yet transcends traditional indicators such as economic growth, productivity and technological innovation to explore social welfare, 'genuine progress' and quality of life issues. The networks of radical institutionalists recognise that the economic, social and psychological aspects are inextricably linked, and that a critical and holistic social science of humanity is in need of advancement. But what other concepts may stimulate an understanding of cultural discontinuity and what governance systems need to be put into place to rectify such anomalies. This

6. A similar theme is discussed in Stanfield (1979a), where he analyses the limits of the exchange paradigm, the problem of emphasising consumer sovereignty, the impact of power on economic processes, and especially the centrality of the concept of "reproduction" in political economy. Power is especially important in this regard. As Stanfield says: "The distortion of power is of especial importance since power is the basic energy of the social system. ... A complete theory of economic power would focus on social reproduction and the formation of economic character. ... Power is exercised through influence in this incessant process of social reproduction. Economic power is the ability to influence those character traits and social relations which are significantly in the structure and working of the economic process. Everyone exercises some influence over this process, and there are myriad bases upon which influence rests. Differential influence is the content of social stratification” (p. 889).

7. Radical institutionalism is a major trend contributed to by Stanfield. It has had a major impact on institutional economics, especially in linking together many of the schools of political economy into what amounts to a more integrative analysis. Radical institutionalism has been able to recognise the need for networks and closer relationships between institutionalism, Marxism, feminism, radical political economy, environmental political economy, and post Keynesian economics. Some of the more important volumes of radical institutionalist work include Dugger (1989), Dugger and Waller (1992), Peterson and Brown (1994), Stanfield (1995), Tilman (1996), Dugger (1996), Brown (1999), O’Hara (2000) and Brown (2002). This tendency to link together themes among the various schools has become a mainstream trend in political economy.

8. This theme is a continual one in Stanfield's writings. He examined it in many different dimensions. For instance, as he said later in the Social Science Journal: "Marxists and institutional traditions are similar in many respects, notably that both are inherently radical in their approaches to the economic system. ... [B]oth intellectual traditions recognize and integrate into their economic theory the basic role played by work and technology. ... Both Marxism and institutionalism seek to demystify the market mechanism and remove the hold of the market mentality over the human mind. Both do so in order that humanity can see the primacy of society and the necessity for social control of economic activity. ... Marxists and institutionalists were among the first to raise the vexing questions concerning the generation of consumer preferences in contemporary capitalism. ... Aggregate instability has long been a primary research area of both Marxism and institutionalism” (Stanfield 1978: 47, 49, 51, 53). The historical and methodological roots of radical institutionalism are examined in Stanfield (2001). 
leads us to notions of the disembedded economy and the Great Capitalist Restoration, analysed in the next two sections.

\section{Karl Polanyi and the Disembedded Economy}

Ron Stanfield's analysis of the economic surplus and the fund for social change provides a conceptual apparatus for understanding the anomalous workings of advanced capitalism. The socioeconomic reproduction of capitalism requires investing resources into institutions to rectify the problem of psycho-cultural malaise characteristic of market society. Karl Polanyi's idea of the disembedded economy explains why the dominance of the market creates system problems. These ideas are detailed in Stanfield's book, The Economic Thought of Karl Polanyi (Stanfield 1986) plus a host of academic articles.

As a result (mainly) of Stanfield's work, the Polanyian concept of the disembedded economy is basic to institutional economics. Polanyi himself was born in Vienna in 1886, and later became a Professor at Columbia in the 1940s and 1950s. His analysis of early cultures taught him both the importance of a "substantive" economics of the way of life of the community, and the need for nonmarket institutions in economic life. In precapitalist societies, for instance, economic institutions were found to be either non-existent or secondary to social and political relationships. This enabled them to slowly evolve through thousands of years of reproduction devoid usually of major system problems.

The problem with market capitalism, according to Polanyi, is that economic relationships of money and commodities dominate political and social institutions, leading to structural and periodic instability. The system is thus continually engaged in varying degrees of uncertainty as the process of change and metamorphosis questions established ways of life. This puts pressure on human beings and nature, leading to cultural and environmental degradation. These "externalities", Stanfield realised, thus become endogenous results of a system that is forever undergoing transformation and destructive creation. Capitalism thus has a principal contradiction that it forever establishes new practices, technologies and skills which require people and nature to perpetually move habitat, upset family linkages and re-establish new habits and relationships. The instabilities of the system adversely impact system reproduction and thereby create periodic structural crises.

Stanfield was the first to systematically analyse the significance of Polanyi's work for institutional economics and economic policy, as well as to situate the disembedded economy in the field of modern political economy. The disembedded tendency revealed to him why certain institutions are required for sustained profit and accumulation, as well as potentially for a new stable social system devoid of massive dislocation. Institutions are needed in economic life to give meaning to people's lives, and also to enable livelihood to be sustainable in the long term. Institutions are, therefore, the very substance of reality that enables people's habits to link with the prevailing norms and mores, thereby enabling social life to be reproduced. Economics thus needs to be a substantive science of real processes and relationships, where the economy is embedded in culture, rather than dominating people's lives so as to dislocate their whole being. Of course, some social institutions are more instrumental to human society than others and therefore need to be critically scrutinised according to the degree to which they are ceremonially dominant. ${ }^{9}$

Essential to Stanfield's cultural political economy is the concept of social transaction or integrative relationship. Three such relationships are conspicuous in Polanyi's work. The first is market exchange, where people meet in a community location, buying and selling goods and services. In the extreme,

9. This reference to instrumental and ceremonial functions of institutions, of course, alludes to the work of Dale Bush and his close colleague Marc Tool, who work in what may be refereed to as the instrumental school of institutionalism. It follows closely from the work of Veblen, John Dewey, Fagg Foster, and others. According to this tendency in institutionalism, instrumental and ceremonial functions of institutions are embedded in all relationships, and the critical thing is the degree to which they are ceremonially encapsulated in the institutions. There is a close linkage between radical institutionalism and instrumental institutionalism, the latter of which may be considered as a radical-liberal wing of the movement. See Bush (2001), Tool (2001a), Tool (2001b) and Tool and Bush (2002) for detail on these ideas. 
market relations become completely anonymous as people buy and sell on the internet, stock market or large supermarket. These market relations are governed by the ethic of equal exchange or quid pro quo, since goods and services exchange for equal value, according to the market. Such forms of exchange are governed by considerations of short-run valuation, devoid of external social valuation; without consideration of the negative costs involved in pollution, stress, dislocation, alienation, and instability. Such prices are designed to heighten profit and spur individual concerns and rewards. Under early forms of society these exchanges tended to be embedded in the cultural arrangements, but under capitalism they take the form mostly of anonymous exchanges in privatised markets.

The second form of integration is reciprocity, where people offer gifts and rewards according to their emotional, cultural or habitual attachment to people. Often this is generated by friendship, where one person offers a gift and the other person may respond sometime in the future with an offer of attachment, material reward or trust. Reciprocal social arrangements are general, multifarious in nature and cultural in their form. They are not based on strict quid pro quo, but rather on transactions associated with communication, sociality, and durable relationships. They seek to embed economy in real lives and cultural attachments, rather than in pure markets. They variously depend on sentiment, person ties and social trust. Strong forms of reciprocity are not likely to stimulate high levels of alienation, social disintegration or long-term ecological destruction since they may be subject to social and moral constraint or system-requirements; but, nevertheless, they do often tend to be imbued in class relationships, ceremonial habits, and networks of power.

The third form of integration is redistribution, usually through some form of state-type apparatus. This is a relatively formal arrangement where a Chief, Council of Elders, Department, or other body obtains funds through, say, taxation or public debt, and redistributes the funds via the social or welfare system or subsidy. These transfer payments are seen as important for social stability and income redistribution to ensure that people and institutions without adequate resources are able to be minimally reproduced. Redistribution can also be activated as lender of last resort facilities through the monetary system, as banking stability becomes a central concern. Deposit insurance also takes this form to potentially reduce uncertainty in the system. Here participants are rewarded according to the extent to which their own resources have been destroyed or stolen to support the system. Recipients are thus paid out of a general social fund.

Polanyi's main point about social transactions is that reciprocity, redistribution and to a lesser extent cultural (not pure) market-place exchange are forms of embeddness. The extent to which anonymous market exchanges dominate over the others indicate the degree to which society is suffering from psycho-cultural malaise. This is a powerful tool of social inquiry where exchange relationships can be critically assessed. In an age of neoliberalism, for instance, the message is clear. Anonymous market relations have been gaining strength during the 1980s-2000s and the system has been undergoing high levels of psycho-cultural crisis. Since people need humane relationships of reciprocity, redistribution and cultural markets, an attempt to dominate society through formal exchange of equivalents will likely lead to inadequate levels of social support.

Indeed, this is exactly what has been happening throughout most of the world over the past two or three decades. In the 1970s, the structural crisis of global and national capital emerged. The dominant response of governance was to reduce cultural and state exchanges in favour of formal market relations. It was hoped that this would re-establish economic performance. However, this failed to occur in most nations as deep recessions and financial instabilities gained momentum in the 1980s, and again in the 1990s and early 2000s. But more fundamentally, social and psychological indicators of well-being and welfare have generally performed even worse than GDP, productivity and levels of financial instability. At a global level, trust, socioeconomic welfare, and environment sustainability have all continued to decline (O’Hara 2006b).

This seems to indicate the power of Polanyi's message about the disembedded economy. It also suggests the need for governance reforms that may re-establish psycho-cultural well-being and a new regime of socioeconomic performance. This links to the concept of the double movement, namely, the 
tendency of capitalist-market systems to both destroy non-market forms of distribution in favour of the impersonal market, and also to re-establish non-market relations periodically when things go especially bad. Stanfield made sense of this by realising that the standard neoclassical theory, especially in its neoliberal form, sought to replace redistribution with market linkages. But since, historically, such a system could not survive due to inadequate public goods or system functions, policy must eventually pave the way for the reestablishment of redistribution, reciprocity and cultural markets. Governance systems thus move through successive waves of free markets to state or community-centred ideology, with neither being able to satisfy fully the system needs of reproduction. It also explains why such ideologies tend to move ahead of practice, since markets cannot exist without institutions and regulations, while states cannot exist without markets and community. Some dynamic balance is required between markets, states and communities but is unlikely to be attained due to the process of institutional adjustment and the power of the vested interests through internal contradictions.

This double movement, for instance, explains many of the changes in economic policy over the past hundred or so years. Just before and during the early years of the Great Depression of the 1930s the dominant policy perspective was the free market ideology, epitomised by the position of the British Treasury. Since the Depression emerged under these conditions, the natural thing was to blame it for severe problems. Hence Keynes's (1936) General Theory, Roosevelt's New Deal, and the British and Swedish trend to state socialism led a movement to increase redistributive mechanisms into the system. This seemed to have the necessary impact as the long boom of the 1950s and 1960s institutionalised the Keynesian-welfare state. However, the onset of problems in the 1970s, led to the opposite movement, to less government, regulation and redistribution. Periodic financial crises and recessions of the 1990s and 2000s is perhaps leading again to an opposite movement of more state power — cum community institutions through the potentially emerging post-Washington consensus. Economic and social policy thus forever weaves and jumps through several runs of double movement, according to trends in socioeconomic indicators (see O’Hara 2009).

Capitalism, thus, needs both formal markets and other forms of redistribution for long term survival. The double movement periodically deepens state forms or market relations, depending on the balance between them and the perception of where problems emanate. The double movement in favour of state forms usually includes a whole host of state activities to re-establish stability and promote conflict resolution. These include, not only lender of last resort facilities, but also discretionary fiscal and monetary policy; worker's compensation for accidents on the job; accords or agreements between unions, capital and the state; deposit insurance and superannuation as well as pension schemes; programs for schools, universities and technical institutions; as well as health programs and infrastructure-enhancement plans. Even the trend to oligopoly and transnational corporations can be seen as a process of protecting institutions from the ravages of competition and free markets to embed economy within society.

But it has to be said that such state programs may sometimes have the opposite effect. This is so because the state (and the market) often destroys relations of reciprocity between individuals and groups; informal socially-centred market relations; plus strong linkages within and between families and communities. As Stanfield emphasised:

The strength of Polanyi's formulation lies in the forceful demonstration that this protective response was not even solely political, in the sense of belonging to the realm of government, much less motivated by a general advance toward leftist ideology. Polanyi denied that the protective response had any unifying theme except the primacy of society and the necessity of taking steps to preserve society in the face of the disruptive onslaught of the uncontrolled market. ... The protective response, in addition to its visibility in the progression of state intervention in industrial relations, natural resources and environment, banking, and so on, can also be seen to be the operative factor in the development of the modern corporation, trusts, and 
unionization. The historical lesson in all of this is the untenability of the self-regulating market economy. [Stanfield 1980: 607]

It is therefore not surprising that the concept of social capital has recently come to the fore, with its emphasis on the need for governance measures that come between (and often within) markets and states. Social capital includes the importance of informal networks between individuals and institutions; trust and sociality to reduce transaction costs and improve communication; as well as the centrality of trust and culture within and between states, communities and markets. All of this is fundamentally Polanyian, and demonstrates the generality of his theoretical apparatus, and its applicability to contemporary issues of governance.

\section{Great Capitalist Restoration, Nurturance and Love}

What, then, are the implications of Ron Stanfield's political economy of institutions and culture for the contemporary workings of capitalism and its system of governance? This is explored through an analysis of the dominant institutions at work in the social economy. These dominant institutional spheres include family and community, ecology and nature, state and government, corporation and production chains, plus markets and money. The great imbedding institutions are those of family and community plus ecology and nature. Family and community include the dominant transactions of reciprocity and redistribution, where nurturance and love have historically generated relationships between people based on sharing and domestic chores.

The past two decades, however, have reproduced contradictory tendencies in this sphere. On the one hand, the positive tendencies create difference and flexibility, where families have become more variable and multifarious in nature, and where members have less control and more fluidity of movement and role. But like every contradiction, the negatives are ever-present and recently have become fairly dominant. Reciprocity and redistribution have declined in the typical Western family as members have become more concerned with the self, and relationships have typically become more unstable and less durable (O’Hara 2006b). The sharing tendency has been replaced by the self-serving trend, leading to less trust and sociality within families and communities (Stanfield and Stanfield 1997), especially in neoliberal-tending economies

The historically embedding institutions of ecology and nature have also become transformed. Traditionally, the natural environment has provided human communities with access to resources such as oxygen, space, material resources, beauty and companionship from other species. But as ecological has made way for business and human capital the natural habitats have been destroyed to often high levels. Species extinction is accelerating as biodiversity diminishes; global warming and dimming are both accelerating as pollutants reduce the degree of sustainability of economic processes; and species stress increases as human population density gets greater and greater.

The corporation was established to provide protection against the market so that firms could survive through long historical time. The long boom of the 1950s and 1960s saw high rates of profit as economies of scale, economies of agglomeration and greater levels of aggregate demand benefited large conglomerates in particular. However, the corporation is undergoing major change through global production networks, complex value chains, and greater competition. The movement of economic activity from the West to East Asia has led to changing power relations and uneven development. While critical areas of Asia are in the process of industrial advancement, much of the rest of the world is in the throws of low profitability due to high levels of competition, the crowding out of domestic investment, and lower levels of productive state spending. High levels of competition are thus reducing profit rates and accumulation tendencies (O’Hara 2006b).

In between families, communities and corporations is the capital-labor nexus. During the 1950s and 1960s there was a relative balance between the power of capital and labor as accords were in place to distribute higher productivity to both profit and wages. The onset of crises in the 1970s and 1980s, however, set in motion changes to industrial relations to try and re-establish profit levels. Thatcherism 
and Reaganomics led the charge of the Great Capitalist Revolution in destroying unions, making working conditions more conducive to the needs of capital, and reducing real wages. These changes led to a greater level of inequality, a reduction in trust between workers and capitalists, and a decline in the empowerment of working class communities.

During the 1950s and 1960s, the state emphasised redistribution very well as welfare and demand management helped to embed economy within society. Worker compensation schemes started to protected labor in high risk areas of mining and manufacturing. The military-industrial complex was critical in protecting certain companies from competition and markets. However, into the 1970s these and other institutions supposedly questioned the historical role of profit and markets. Capitalism was under threat from a society that was starting to question its operational dynamics. The state, therefore, led the charge to re-establish business values through attempts to reduce regulations and protections. The Great Capitalist Restoration through neoliberalism strengthened the rule of private property, product innovation and the institutions of competition. In the process it inhibited aggregate demand, global accord and the need for institutional protection for family and community.

The institutions of the market, therefore, were reinforced during the 1980s-2000s, while reciprocity and redistribution were inhibited. The domestic financial market, foreign capital market and labor market were all deregulated during the 1970s-1990s. People were encouraged, especially in neoliberaltending economies, to promote their own individual interests, be all they can be, and reinvigorate the American dream. Fewer people joined unions, political groups, bowling clubs, and community organisations. People put resources into work and study; plus groups promoting financial security, personal fitness and psychological health. As a result, nurturance and love declined in favour of self and the 'me generation'. Market transactions increased at the expense of reciprocity and redistribution. The disembedded economy deepened while financial and corporate crises gained in amplitude. As Ron and Jackie Stanfield say:

In conclusion, our case can be put simply: America is in the throws of a Nurturance Gap. Its symptoms are the losses of childhood, dignity, intimacy, and civility. The social bonds which induced nurturing labor are rooted in reciprocity and redistribution. Economic stress, cultural change, and ideological neglect are undermining reciprocity and redistribution. Habitually preoccupied with invidious status in the income rat-race, we are too busy to nurture each other. The positive or virtuous circle of reciprocity is necessary to hold society together: people caring and respecting others because they expect others and respect them. Neglect engenders a vicious circle. A Nurturance Gap ensures. People become mean-spirited and intemperate. Cynical. Even dangerous. [Stanfield and Stanfield 1997: 121]

There is emerging a backlash against neoliberalism in the form of the post-Washington consensus, progressive governments in Latin America, and the post-autistic movement in political economy. The double movement is being seen daily in national and global economies. The policy implications of these changes are that financial and corporate institutions need to have greater stability to prevent the rise and fall of massive speculative bubbles and corporate crises. Asset backed reserve requirements and changing accounting cultures are required to reduce fraud and conflicts of interest. More productive government spending is needed to promote social capabilities in the areas of education, health, infrastructure, communication, while public utilities should enhance essential consumption. Social institutions should be reorganised, including the work environment to promote participatory democracy and work-family relations to stimulate trust and sociality. International relations seriously depend on successful multilateral agreements and effective global institutions to protect the rule of law, sovereign governments, the environment, and threats to security. The new vision is holistic, integrative, participatory, and cognizant of the potential problems of situating the individual outside the social fabric. Governance needs to balance agency and structure, with a long-term vision and recognition of the problems besetting class, ethnicity, gender and nation. 


\section{Conclusion}

Ron Stanfield has for over thirty years and continues to be an energetic contributor to social and political economy. He has made major inroads into institution-building at Colorado State University, as well as within professional organisations such as the Association for Evolutionary Economics, the Association for Social Economics and the Association for Institutional Thought. He has been a leader of the radical institutional movement that seeks to comprehend the nature and problems of neoliberal capitalism in terms of psycho-cultural degradation and environmental pollution. He has promoted trust and sociality among scholars to improve their well being and contribute to a shared yet critical understanding of contemporary capitalism. He has contributed to the policy debate vis-à-vis the double movement and the importance of public goods and social institutions solving socioeconomic problems. He has been a good friend and comrade to many people.

What lies ahead for Stanfield and others in enhancing areas where he has made inroads to scholarly inquiry? Currently his research is continuing on various fronts, so the central issues are evolving and becoming more complex through time. But some suggestions can be made about the future course of analysis. The first area is in the field of institutional building in heterodox economics. Stanfield laid the path of how to build trust and sociality between political economists through individual scholarly interaction, associations, and the advancement of conceptualisation and methodology. We need to build on his gregarious tendencies and share friendship and networks in order to promote trust between scholars. This requires the building of sympathetic networks of scholars to scrutinise the dominant contradictions of contemporary capitalism.

The second area relates to the question of socioeconomic reproduction. Stanfield showed us, more than any other scholar, how to advance our understanding of system-building through institutional development. We need to go beyond deterministic methods and economistic tools to develop a grand social science dealing with systems, norms and habits in evolution and crisis. To do this it is necessary to advance our understanding of how the economy is situated within culture, and how it is critical for society to embed economy rather than the reverse. Developing social structures of accumulation and instrumental institutions that advance long term progress is the central requirement of political economy. Such work on progressive governance is critical to the future course of society.

Thirdly, the economic surplus provides a way of comprehending the operational dynamics of socioeconomic systems. We need to advance our understanding of how the surplus represents a social fund for progressive change and motion. This research program is in its early phase of development. In order to advance this program it is necessary to apply the tools of political economy to questions such as how can we redirect social priorities to progressive governance. We need to study the production and distribution of the economic surplus so as to reduce alienation, war, and instability. We need to link the economic surplus to questions of class, gender and ethnic divisions and how to promote conflict resolution. We need to comprehend how the economic surplus can be utilised to stimulate reproduction through the advancement of public health, education, physical infrastructure, communication networks and community development. Also it can be applied to alternative measurements of socioeconomic progress and the analysis of superfluous goods and services that waste the surplus.

It is also necessary to advance inquiry into the double movement and the associated development of institutions to promote an embedded economy within society. This involves work on lender of last resort facilities and how they may reduce moral hazard while promoting stability; conflict resolution programs between capital and labor so as to enrich the work experience, and in the process enhance productivity; as well as ways of promoting strong sustainability through promoting the public goods of environmental capital and ecological sustenance. Also critical in this is the promotion of love and nurturance through the generation of trust and sociality. We need to build a nurturing society where the ends are humane, sustainable and relatively stability. 
James Ronald Stanfield taught us to treat the economy as a social system with humanity and the environment at its core. Economics should not be a mere play thing for promotion and individual enhancement. It is necessary to understand and promote both individuality and sociality concurrently. This can be done through a paradigm that treats structure and agency as co-dependent, and a progressive agenda that deepens participatory social processes and community linkages. Nurturance, friendship, and love need to be advanced while promoting livelihood and material advance for the majority of the population. The cleavages of class, ethnicity, gender and nation can be moderated through a progressive agenda of reform. This is the basic message to be learnt from the continuing work of Ron Stanfield. We can do nothing better than take him as a point of departure for how best to understand political economy and promote social change.

\section{References}

Baran, P.A. (1957) The political economy of growth. Harmondsworth, Penguin, 1968.

Baran, P.A. and Sweezy, P.M. (1966) Monopoly capital: An essay on the American economic and social order. Harmondsworth: Penguin, 1968.

Brown, D.M. (1988) Towards a radical democracy: The political economy of the Budapest school. London and Boston: Unwin Hyman Books.

Brown, D.M. (1998) (Ed) Thorstein Veblen in the twenty-first century: A commemoration of 'The theory of the leisure class' (1899-1999). Cheltenham, UK \& Northampton, US: Edward Elgar.

Brown, D.M. (2002) Insatiable is not sustainable. Westport, Connecticut \& London, UK: Praeger.

Bush, P.D. (2001) Institutional change and adjustment. In P.A. O’Hara (Ed.), Encyclopedia of Political Economy (pp. 520-523). London and New York: Routledge. Paper Edition.

Dugger, W.M. (1989) (Ed) Radical institutionalism: Contemporary voices. New York \& London: Greenwood Press.

Dugger, W.M. (1996) Inequality: Radical institutional views on race, gender, class and nation. New York \& London: Greenwood Press.

Dugger, W.M. and Waller, W. (1992) (Eds.) The stratified state: Radical institutionalist theories of participation and duality. London \& Armonk, NY: M.E. Sharpe.

Halperin, R.H. (1994) Marx's institutional paradigm and Polanyi's generic model of the economy. In R.H. Halperin, Cultural economies: Past and present (pp. 34-54). Austin: University of Texas Press.

Godelier, Maurice. (1986) Karl Polanyi and the "shifting place” of the economy in societies", in M.Godelier, The mental and the material: Thought economy and society. London: Verso. Translated by Martin Thom.

Gordon, D.M; Weisskopf, T.E. and Bowles, S. (1994) Power, accumulation, and crisis: The rise and demise of the postwar social structure of accumulation. In V.D. Lippit (Ed.), Radical political economy: Explorations in alternative economic analysis. (pp. 226-246). Armonk, NY \& London, UK: M.E. Sharpe.

Holton, R.J. (1992) Economy and society. London and New York: Routledge.

Hodgson, G.M. (2000) Karl Polanyi (1886-1954). In P. Arestis and M. Sawyer (Eds.), A biographical dictionary of dissenting economists (pp. 333-339). Second Edition. Chaltenham, UK \& Northampton, US: Edward Elgar.

Lawn, Philip. (2003) "A theoretical foundation to support the index of sustainable economic welfare (ISEW), the genuine progress indicator (GPI) and other related indexes”, Ecological Economics, 44(1), 106-188.

Mingione, Enzo. (1991) Fragmented societies: A sociology of economic life beyond the market paradigm. Oxford \& Cambridge: Basil Blackwell.

O’Connor, James. (1984) Accumulation crisis. Oxford: Blackwell Publishers. 
O’Hara, Phillip Anthony. (2000) Marx, Veblen and contemporary institutional political economy: Principles and unstable dynamics of capitalism. Cheltenham, UK \& Broookfield, US: Edward Elgar.

O’Hara, Phillip Anthony (2006a) The economic surplus, disembedded economy and nurturance gapThe contribution of James Ronald Stanfield to political economy. Journal of Economic Issues, 40(2), 507- 516

O’Hara, Phillip Anthony. (2006b) Growth and development in the global political economy: Social structures of accumulation and modes of regulation. London and New York: Routledge/Taylor and Francis.

O’Hara, Phillip Anthony. (2009) (Ed.) International encyclopedia of public policy. 4 volumes. Perth:

GPERU. http://pohara.homestead.com/Encyclopedia/Volume-1.pdf

Peterson, Janice and Doug Brown. (1994) The economic status of women under capitalism: Institutional economics and feminist theory. Aldershot, UK and Brookfield US: Edward Elgar.

Phillips, Ronnie J. (1995a) (Ed.) Economic mavericks: The Texas institutionalists, Press, Greenwood, CT: Jai Press.

Phillips, Ronnie J. (1995b) The Chicago plan and New Deal banking reform, Armonk, NY: M.E. Sharpe Inc.

Polanyi, Karl. (1968) Primitive, archaic, and modern economies: Essays of Karl Polanyi. Boston: Beacon Press. Edited by George Dalton.

Polanyi, Karl. (1944) The great transformation. Boston: Beacon Press, 1957

Stanfield, J.R.. (1973) The economic surplus and neo-Marxism. Lexington, Massachusetts; London, UK: Lexington Books.

Stanfield, J.R.. (1974) A revision of the economic surplus concept, Review of Radical Political Economics, 6(3), 69-77. Reprinted in Foster, J.B. and Szlaijfer, H. (Eds.), The faltering economy: The problem of accumulation under monopoly capitalism. New York: Monthly Review Press, pp. 251-261.

Stanfield, J.R.. (1974) Kuhnian scientific revolutions and the Keynesian revolution”, Journal of Economic Issues, 8(1), 97-109.

Stanfield, J.R.. (1975) Legitimacy and value in corporate society, Nebraska Journal of Economics and Business, 14(Winter), 3-18.

Stanfield, J.R.. (1977) Limited capitalism, institutionalism and Marxism, Journal of Economic Issues, 11(1), 61-71.

Stanfield, J.R.. (1978) Radical economics, institutionalism, and Marxism, Social Science Journal, 14(1), 47-54.

Stanfield, J.R.. (1979) Economic thought and social change. Carbondale \& Edwardsville, US and London \& Amsterdam: Southern Illinois University Press and Feffer and Simons Inc.

Stanfield, J.R.. (1979a) Phenomena and epiphenomena in economics, Journal of Economic Issues, 13(4), 885-898.

Stanfield, J.R.. (1980) The institutional economics of Karl Polanyi, Journal of Economic Issues, 14(3), 593-614.

Stanfield, J.R.. (1982) Toward a new value standard in economics, Economic Forum, 13(Fall), 67-85.

Stanfield, J.R.. (1982) Learning from primitive economies, Journal of Economic Issues, 16(2), 471-9.

Stanfield, J.R.. (1986) The economic thought of Karl Polanyi: Lives and livelihood. New York; St Martins Press.

Stanfield, J.R.. (1989) Veblenian and neo-Marxian perspectives on the cultural crisis of late capitalism, Journal of Economic Issues, 23(3), 717-734.

Stanfield, J.R.. (1990) Understanding the welfare state: The significance of social economics”, in M.L. (Ed.), Social Economics: Retrospect and Prospect. Boston, US \& London, UK: Kluwer Academic Publishers. 
Stanfield, J.R.. (1992) The fund for social change. In Davis, J.B. (Ed.), The economic surplus in advanced economies. (pp. 130-148). Aldershot, UK: Edward Elgar.

Stanfield, J.R.. (1994) Karl Polanyi. In Hodgson, G.M., Samuels, W.J., and Tool, M.R. (Eds), The Elgar companion to institutional and evolutionary economics. L-Z. Aldershot, UK \& Vermont, US: Edward Elgar.

Stanfield, J.R. (1995) Economics, power and culture: Essays in the development of radical institutionism. New York: St. Martin's Press.

Stanfield, J.R. (1996) John Kenneth Galbriath. New York: St Martin’s Press.

Stanfield, J.R.. (1999) The scope, method, and significance of original institutional economics, Journal of Economic Issues, 33(2), 231-55.

Stanfield, J.R.. (2001) Radical institutionalism. In O’Hara, P.A. (Ed.), Encyclopedia of political economy (pp. 955-957). London and New York: Routledge.

Stanfield, J.R. and Jaqueline Bloom Stanfield. (1997) Where has love gone? Reciprocity, redistribution, and the nurturance gap, Journal of Socio-Economics, 26(2), 111-127.

Tilman, Rick. (1996) The intellectual legacy of Thorstein Veblen: Unresolved issues. London \& Westport, Connecticut: Greenwood Press.

Tool, M. (2001a) Instrumental value theory. In P.A. O’Hara (Ed.), Encyclopedia of political economy (pp. 538-541). New York and London: Routledge.

Tool, M. (2001b) The discretionary economy: A normative theory of political economy. Philadelphia: Transaction Press.

Tool, M. and Bush, P.D. (2002) Institutional analysis and policy. Boston: Kluwer Academic Publishers.

Phillip Anthony O'Hara is Professor of Global Political Economy and Governance at the Global Political Economy Research Unit, Economics Department, Curtin University, Perth, Australia. He won the 2002 Gunnar Myrdal Award from the European Association for Evolutionary Political Economy, and the 1998 Clarence Ayres Award from the Association for Evolutionary Economics (AFEE), based in the USA. He is on the editorial boards of the Journal of Economic Issues, the Review of Social Economy, the European Journal of Economics and Economic Policy, and the International Journal of Economics Education and Pluralism. He works in the areas of principles of political economy, social structures of accumulation, policy and governance, and political economy biography. See http://pohara.homestead.com/files/CV.pdf Email: philohara@yahoo.com 
Table 1: Stanfield's Notable Achievements in Political Economy

\begin{tabular}{|c|c|c|c|c|c|c|c|}
\hline $\begin{array}{l}\text { Books - } \\
\text { Topic }\end{array}$ & $\begin{array}{c}\text { Refereed } \\
\text { Journal } \\
\text { Articles }\end{array}$ & $\begin{array}{c}\text { Book } \\
\text { Chapters }\end{array}$ & $\begin{array}{c}\text { Book } \\
\text { Reviews }\end{array}$ & PhD Students - Topic & Awards & President & Professional Offices \\
\hline 7 & 57 & 32 & 49 & 17 & 7 & 3 & 7 \\
\hline $\begin{array}{l}\text { 1. Economic } \\
\text { Surplus }\end{array}$ & 3 & 2 & & $\begin{array}{c}\text { Gene Peterson - Marxian/Catholic Thought } \\
\text { William Kern - Friedrich Hayek } \\
\text { Raymond Benton - Cultural System } \\
\end{array}$ & $\begin{array}{l}\text { Veblen-Commons } \\
\text { Award (2006) }\end{array}$ & AFEE & $\begin{array}{l}\text { Rocky Mountain } \\
\text { Regional Coordinator }\end{array}$ \\
\hline 2. Social Change & 12 & 8 & & $\begin{array}{c}\text { Ernest Diedrich - Pathology of Growth } \\
\text { Douglas Brown - Budapest School } \\
\text { Brent McClintock - Welfare State } \\
\end{array}$ & $\begin{array}{l}\text { Thomas Divine Award } \\
\text { (2002) }\end{array}$ & ASE & Editorial Board JEI \\
\hline 3. Karl Polanyi & 8 & 3 & & $\begin{array}{c}\text { Michael Wilson - Housing } \\
\text { Michael Carroll - Robert Heilbroner } \\
\text { Douglas Kinnear - Institutional Labor Economics }\end{array}$ & $\begin{array}{c}\text { John Stern } \\
\text { Distinguished Professor } \\
\text { (1999) }\end{array}$ & AFIT & $\begin{array}{l}\text { Executive Council } \\
\text { ASE }\end{array}$ \\
\hline $\begin{array}{l}\text { 4. Radical } \\
\text { Institutionalism }\end{array}$ & 11 & 6 & & $\begin{array}{c}\text { Aric Krause - Information Infrastructure } \\
\text { Robert LaJeunesse - Work Time } \\
\text { Thomas Kemp - John Commons }\end{array}$ & $\begin{array}{l}\text { Nomura Foundation } \\
\text { Plenary Speaker (1998) }\end{array}$ & & $\begin{array}{l}\text { Board of Directors } \\
\text { AFEE }\end{array}$ \\
\hline $\begin{array}{l}\text { 5. J.K. Galbraith } \\
\text { 6. J.K. Galbriath } \\
\text { Interviews }\end{array}$ & 7 & 3 & & $\begin{array}{c}\text { Tim Wunder - Veblen \& Schumpeter } \\
\text { Mary Wrenn - Heterodox Economics } \\
\text { Kurt Keiser - Rexford Tiugwell }\end{array}$ & $\begin{array}{l}\text { Pennock Distinguished } \\
\text { Service Award (1988- } \\
\text { 89) }\end{array}$ & & $\begin{array}{l}\text { Executive Council } \\
\text { WSSA }\end{array}$ \\
\hline \multirow[t]{2}{*}{$\begin{array}{l}\text { 7. Economy and } \\
\text { Society }\end{array}$} & 16 & 10 & & $\begin{array}{l}\text { Laura Taylor - Transitional Economies } \\
\text { Pamela Jackson - News Media }\end{array}$ & $\begin{array}{l}\text { Helen Potter Award } \\
\text { (1975) }\end{array}$ & & $\begin{array}{l}\text { International } \\
\text { Advisory Board } \\
\text { ASPE }\end{array}$ \\
\hline & & & & & $\begin{array}{c}\text { Omicron Delta Epsilon } \\
\text { (1969) }\end{array}$ & & $\begin{array}{l}\text { Associate Editor, } \\
\text { RoSE }\end{array}$ \\
\hline
\end{tabular}

